\title{
EKSISTENSI GRUP MUSIK DANGDUT BHARATA DESA BENTAR KECAMATAN SALEM KABUPATEN BREBES
}

\author{
Gretta Nidzar Risna \\ Suharto
}

Jurusan Sendratasik, Fakultas Bahasa dan Seni, Universitas Negeri Semarang, Indonesia

\begin{tabular}{l} 
Info Artikel \\
\hline Sejarah Artikel: \\
Diterima Maret 2016 \\
Disetujui April 2016 \\
Dipublikasikan Mei 2016 \\
Keyword :Existence, \\
Bharata Dangdut Music \\
Group
\end{tabular}

Semarang, 50229

Email : grettanidzarlagi@yahoo.co.id

\section{AlamatKorespondensi \\ Gedung B2 Lantai 2 FBS Unnes \\ KampusSekaran, GunungPati,}

Tujuan penelitian ini adalah untuk mengetauhi dan mendeskripsikan eksistensi Grup Musik Dangdut Bharata Desa Bentar Kecamatan Salem Kabupaten Brebes. Teknik pengumpulan data dilakukan dengan observasi, wawancara dan studi dokumentasi. Data yang diperoleh antaralain rekaman wawancara, foto, video pertunjukan dan dokumen pribadi grup musik dangdut Bharata. Hasil penelitian menunjukan bahwa Eksistensi Grup Musik Dangdut Bharata masih bisadipertahankan hingga saat ini karena grup ini memiliki strategi yang baik dalam pemasaran dan pertunjukan. Dalam setiap pertunjukan grup ini selalu mengemas penampilannya dengan menarik dan berbeda baik dari segi kualitas musik dan dekorasi panggung dengan grup yang ada di sekitar Kecamatan Salem, sehingga grup ini menjadi daya tarik tersendiri dan mendapat tempat istimewa di hati masyarakat penggemar dangdut. Selain strategi yang baik, grup musik dangdut Bharata juga selalu konsisten untuk menampilkan pertunjukan terbaik dalam setiap acara hiburan, konsisten dalam meningkatakan kualitas musik, sehingga keberadaan Grup Musik Dangdut Bharata diakui masyarakat hingga saat ini dengan banyaknya tawaran pentas diberbagai acara hiburan.

\section{PENDAHULUAN}

Dangdut merupakan pertunjukan musik di Indonesia yang lebih populer di mata masyarakat Indonesia terlihat pada padatnya penonton pada saat ada pertunjukan musik dangdut (Muttaqin, 2006:110). Frederick, (1982:83), mengatakan bahwa musik dangdut seringkali dilecehkan, dicap imitasi, tanpa identitas, dan tidak bermutu.Musik ini memiliki ciri khas yaitu di dalam membawakannya menggunakan cengkok yangmendayu-dayu yang diikuti detak atau ketukan gendang. Musik ini didominasi oleh "denyut iramatarian" atau joget, mengandung pesan populis, dan ditujukan kepada para remaja (Irawati1987:46). Tema-tema lagu dangdut mengangkat kenyataan hidup masyarakat sehari-hari. Banyakyang terasa lugas, tanpa ditutup-tutupi sehingga dapat diterima 
khalayak dan terasa lebih dekatdengan masyarakat (Ukat 1990:5)

Di kabupaten Brebes, khususnya di kecamatan Salem, musik dangdut sangat digemari masyarakat. Apalagi dengan maraknya acara dangdut yang disiarkan di stasiun televisi lokal maupun swasta, pamor musik dangdut yang sudah mulai menurun kini terdongkrak kembali ke papan atas musik indonesia. Ditambah lagi dengan penggarapan musik dangdut yang kian modern, membuat musik dangdut kian bersaing dengan aliran musik- musik yang lain.

Bharata adalah nama grup musik dangdut yang berasal dari Desa Bentar, Kecamatan Salem, Kabupaten Brebes. Grup ini menjadi favorit masyarakat Kecamatan Salem. Hal ini dibuktikan dengan seringnya grup musik dangdut Bharata ini mendapatkan tawaran pementasan di sekitar Kecamatan Salem. Selain itu, dalam setiap pementasan grup musik dangdut Bharata selalu ramai oleh masyarakat yang antusias untuk menyaksikan penampilan grup musik dangdut Bharata. Hal ini dikarenakan penampilan yang disajikan grup musik dangdut Bharata baik dari segi musik yang dihasilkan, maupun dari segi visual sangat menghibur.

Pembawaan lagu-lagu yang enerjik dan sedang laris di pasaran, menjadi daya pikat tersendiri bagi penonton. Selain itu tata panggung dan perlengkapan yang digunakan grup musik dangdut Bharata dalam setiap pementasan cukup lengkap. Hal ini yang membuat sekelompok pemuda dari desa Bentar menamai kelompok mereka dengan nama Bharata Fans Club. Grup musik ini mengadakan pementasan di acara hajat atau di acara-acara peringatan hari besar di Kecamatan Salem. Sebagai bukti kualitas yang dimiliki dalam bermain musik, Grup musik dangdut Bharata ini pernah meraih prestasi dalam ajang lomba, yaitu gelar juara pertama dalam acara lomba grup musik dangdut yang diselenggarakan oleh PAMMI (Persatuan Artis Musik Melayu Indonesia) Kabupaten Brebes pada bulan juli tahun 2011.
Selain mendapat juara pertama pada gelaran tersebut, beberapa pemain pun mendapat juara yaitu sebagai vokal pria dan wanita terbaik, pemain bass terbaik, dan pemain suling terbaik.Dengan prestasi dan kualitas musik yang dimiliki, saat ini Grup musik dangdut Bharata sudah sering menerima dan mengadakan pementasan di luar kecamatan hingga luar kabupaten Brebes, salah satunya yaitu di Kabupaten Cilacap dan Kabupaten Kuningan Provinsi Jawa Barat.

Dari latar belakang masalah di atas, maka penulis tertarik untuk meneliti dan menuliskannya ke dalam bentuk tulisan ilmiah berupa skripsi, dengan judul: "Eksistensi Grup Musik Dangdut Bharata Desa Bentar Kecamatan Salem Kabupaten Brebes".

\section{METODE PENELITIAN}

Metode yang dipakai dalam penelitian ini adalah metode penelitian kualitatif, sedangkan teknik penyajiannya dalam bentuk deskriptif. Teknik pengumpulan data yang digunakan dalam penelitian ini adalah teknik observasi, wawancara, dan studi dokumen.Moleong (2010: 6) mengatakan bahwa penelitian deskriptif kualitatif adalah penelitian yang bermaksud memahami fenomena tentang apa yang dialami oleh subjek penelitian misalnya perilaku, persepsi, motivasi, tindakan dan lain-lain, secara holistik dan dengan cara deskriptif dalam bentuk katakata dan bahan, pada suatu konteks khusus yang alamiah dan dengan memanfaatkan berbagai metode alamiah.

\section{Sasaran Penelitian}

Objek penelitian ini meliputi eksistensi grup musik dangdut Bharata Desa Bentar Kecamatan Salem Kabupaten Brebes. Sedangkan subjeknya adalah para pemain dan pimpinan grup musik dangdut Bharata.

\section{Teknik Pengumpulan Data}

Teknik pengumpulan data yang digunakan dalam melakukan penelitian adalah dengan :

\section{Observasi}


Pelaksanaan observasi dalam penelitian ini dilakukan langsung pada saat grup musik dangdut Bharata pentas di beberapa acara khajatan. Hal ini bertujuan agar menghasilkan data dara yang terbaru tentang bagaimana eksistensi grup musik dangdut Bharata pada saat ini.

\section{Wawancara}

Dalam melakukan wawancara, pengumpul data telah menyiapkan instrumen penelitian berupa pertanyaan-pertanyaan tertulis yang alternatif jawabanya pun telah dipersiapkan. Wawancara dilakukan dengan beberapa narasumber yaitu pimpinan grup, Bapak Juni Sunendar, Pemain Musik dangdut Grup Bharata, Penyanyi, dan Konsumen grup musik dangdut Bharata.

\section{Dokumentasi}

Studi dokumen merupakan pelengkap dari penggunaan metode observasi dan wawancara dalam penelitian kualitatif.Metode dokumentasi dilakukan pada saat peneliti sedang mewawancarai beberapa sumber serta proses pementasan grup musik dangdut Bharata . Dokumentasi ini digunakan utuk mencari data-data mengenai hal yang berhubungan dengan faktor-faktor yang mempengaruhi eksistensi grup musik dangdut Bharata pada saat ini.

\section{Teknik Pemeriksaan Keabsahan Data}

Teknik pengumpulan data yang digunakan dalam penelitian ini adalah triangulasi. Triangulasi diartikan sebagai teknik pengumpulan data yang bersifat menggabungkan dari berbagai teknik pengumpulan data dan sumber yang telah ada.

\section{Teknik Analisis Data}

Analisis data adalah proses mencari dan menyusun secara sistematis data yang diperoleh hasil dari wawancara, catatan lapangan, dan bahan-bahan lain, sehingga dapat mudah dipahami, dan temuanya dapat diinformasikan kepada orang lain.

\section{HASIL DAN PEMBAHASAN}

\section{Grup Musik Dangdut Bharata}

Bharata adalah sebuah grup musik dangdut yang berasal dari Desa Bentar, Kecamatan Salem, Kabupaten Brebes. Grup musik ini berdiri sejak tahun
2009 yang diprakarsai oleh bapak Juni Sunendar. Sebelum grup dangdut ini dibentuk, sudah ada grup musik dangdut di kecamatan Salem yaitu Grup musik dangdut Arjuna. Awalnya bapak Juni Sunendar memulai karir musik dangdutnya di kota Semarang, sebagai pemain suling, namun hanya sekedar hobi saja guna mengisi waktu luangnya dengan para pemuda sesama penggemar musik dangdut. Karena pekerjaan memaksa beliau untuk pindah, akhirnya beliau melanjutkan hobinya bermain musik dangdut di Desa Bentar. Namun di Desa Bentar ini beliau memutuskan untuk menekuni hobinya dan menjadikannya pekerjaan sampingan guna mengisi waktu luang dan menambah pendapatan. Akhirnya beliau bergabung dengan grup musik dangdut Arjuna.

Pada saat itu grup musik Arjuna sering sekali mendapatkan job pentas di tempat-tempat hajat maupun acara besar lain. Dalam grup Arjuna ini, bapak Juni Sunendar tidak lagi sebagai pemain suling, namun sudah bisa bermain sebagai pemain keyboard atau pada saat itu biasa disebut dengan pemain organ. Hampir tiap bulan grup ini menjalani pentas di tempat hajat, bahkan pada bulan tertentu seperti syawal, grup ini bisa manggung tiap hari berturut-turut dalam 1 minggu.

Seiring dengan larisnya grup dangdut Arjuna ini, grup ini pun semakin berkembang namun hampir seluruh personil merasa mereka tidak dianggap dan diterlantarkan, karena grup ini lebih sering menggunakan pemain cabutan dari grup yang berada diluar kecamatan Salem. Maka para pemain pun termasuk bJuni pak Sunendar berunding dan memutuskan untuk keluar dari grup tersebut. Setelah keputusan itu, hubungan antara pemain dan pimpinan tersebut seketika bertolak belakang.

Setelah grup dangdut Bharata ini dibentuk, grup ini tidak semata - mata langsung bisa mendapatkan job pentas di acara-acara hajat. Sebagai grup dangdut baru, tentunya grup ini masih kesulitan untuk mendapatkan tawaran pentas. Meskipun demikian, pimpinan grup bapak Juni Sunendar tidak patah semangat dalam mencari job agar grup 
dangdutnya bisa tampil di acara-acara hajatan atau acara hiburan lain.

Seiring dengan berjalannya waktu dan kerja keras dari para personil grup musik dangdut Bharata dalam memberikan sajian musik yang terbaik, grup musik dangdut Bharata akhirnya benar-benar diakui oleh masyarakat dalam bentuk profesional bisnis yang siap melayani kebutuhan hiburan bagi masyarakat luas.

Karena merasa keadaan seperti ini merugikan mereka, akhirnya bapak Juni Sunendar yang bekerja sama dengan bapak Karta Atmanegara memutuskan untuk mendirikan sebuah grup musik dangdut yang diberi nama Bharata. Kata Bharata sendiri diambil dari bahasa pewayangan yaitu " Bharata Yudha " yang artinya Saudara. Seperti yang dituturkan bapak Juni Sunendar, harapan dari diberikannya nama Bharata itu sendiri yaitu mudah - mudahan grup musik ini dapat membawa rasa persaudaraan bagi semua orang.

Lokasi berkumpul grup musik dangdut Bharata yaitu terletak di kediaman Bpk Juni Sunendar yaitu Jl. Kauman no 4 Desa Bentar. Rumah ini biasa digunakan para anggota grup musik dangdut Bharata untuk beristirahat selepas pentas, juga untuk tempat berdiskusi mengenai permasalahan yang terjadi di grup.

\section{Eksistensi Grup Musik Dangdut Bharata Desa}

Bentar, Kecamatan Salem, Kabupaten Brebes

Menurut Zainal Abidin (2008) eksistensi tidak bersifat kaku dan terhenti, melainkan lentur dan mengalami perkembangan atau sebaliknya kemunduran, tergantung pada kemampuan individu dalam mengaktualisasikan potensi-potensinya.Oleh sebab itu, arti istilah eksistensi analog dengan 'kata kerja' bukan 'kata benda'.Eksistensi adalah milik pribadi.Tidak ada dua individu yang identik.Oleh sebab itu, eksistensi adalah milik pribadi, yang keberadaannya tidak bisa disamakan satu sama lain.Sedangkan menurut Abidin Zaenal (2007:16) eksistensi adalah suatu proses yang dinamis, suatu, menjadi, atau mengada. Ini sesuai dengan asal kata itu sendiri yakni exsistere, yang artinya keluar dari, melampaui atau mengatasi. Jadi eksisteni tidak bersifat kaku dan terhenti, melainkan lentur atau kenyal dan mengalami perkembangan atau sebaliknya kemunduran, tergantung kemampuan dalam mengaktualisasikan potensi - potensinya.

Eksistensi bisa diartikan sebagai suatu keberadaan. Dalam hal ini, eksistensi yang dibahas yaitu mengenai keberadaan suatu grup musik dangdut.Menurut Irfan (2015:26) eksistensi adalah paham yang cenderung memandang manusia sebagai objek hidup yang memiliki taraf yang tinggi, dan keberadaan dari manusia ditentukan dengan dirinya sendiri bukan melalui rekan atau kerabatnya, serta berpandangan bahwa manusia adalah satu-satunya mahluk hidup yang dapat eksis dengan apapun disekelilingnya karena manusia disini dikaruniai sebuah organ urgen yang tidak dimiliki oleh mahluk hidup lainnya sehingga pada akhirnya mereka dapat menempatkan dirinya sesuai dengan keadaan dan selalu eksis dalam setiap hidupnya dengan organ yang luar biasa hebat tersebut.

Berkaitan dengan eksistensi grup musik, grup musik itu sendiri dianggap eksis ketika memenuhi beberapa syarat diantaranya harus memnpunyai strategi. Strategi diperlukan untuk menyusun berbagai kegiatan yang mendukung bahwa grup itu layak dianggap keberadaannya. Grup musik harus konsisten, maksudnya adalah mereka harus menjaga kualitas dan ciri khas dari grup itu sendiri. Biasanya diwujudkan dengan mengadakan berbagai acara dengan ide gagasan yang menarik, inovatif, dan menonjolkan kekhasan dari grup itu sendiri. Grup musik dianggap eksis juga harus melalui proses peengakuan. Pengakuan baik dari masyarakat umum maupun dari Dinas pemerintah terkait.

Hal pertama yang harus dilakukan oleh grup musik yaitu memiliki strategi. Sebuah grup harus memiliki strategi bagaimana cara agar grup tersebut bisa terus bertahan ditengah persaingan dan tuntutan konsumen sehingga tetap bisa menjaga keberadaanya. Strategi tersebut tentunya akan terus berkembang 
sesuai dengan tuntutan dari masyarakat sebagai konsumen dan penikmat musik dangdut.

Hal kedua yang harus dilakukan grup musik yaitu konsiten. Grup musik harus menjaga konsistensinya dalam menyajikan penampilan musik yang terbaik. Penyajian yang diberikan pun harus selalu ada dalam tingkatan maksimal. Selain itu, grup musik juga harus konsisten dalam menjaga ciri khas yang membedakan grup tersebut dengan grup lain, sehingga keberadaan grup musik tersebut dapat terjaga dan diakui masyarakat. Hal terakhir yaitu grup tersebut harus melalui proses pangakuan.Pengakuan dalam hal ini yaitu pengakuan dari masyarakat sebagai penanggap (konsumen) grup musik dangdut Bharata dan masyarakat sebagai penonton.

Grup musik Bharata adalah sebuah grup musik yang berdiri sejak enam tahun lalu. Sejak pertama kali dibentuk, grup musik dangdut Bharata sudah melakukan banyak hal untuk terus mempertahankan keberadaannya. Penyajian grup musik dangdut Bharata terus dikembangakan agar dapat menampilkan hiburan musik dangdut bagi masyarakat. Selain karena terus memperbaiki penyajian musik dalam setiap pementasannya, keberadaan grup musik dangdut Bharata pun didukung oleh banyaknya masyarakat di sekitar Kecamatan Salem yang menyukai musik dangdut dan berusaha untuk terus melestarikan musik asli negeri sendiri. Ciri khas musik dangdut yang enak untuk berjoget, membuat para penggemar musik dangdut tidak pernah berkurang. Apalagi didukung dengan banyaknya acara musik di televisi yang mengambil tema musik dangdut, baik itu ajang pencarian bakat atau hiburan semata, diakui banyak menambah jumlah penggemar musik dangdut di Indonesia. Hal tersebut secara tidak langsung berdampak positif bagi grup musik dangdut Bharata, karena setelah musik dangdut menjadi booming, tawaran pentas untuk grup musik dangdut Bharata pun meningkat.Grup musik dangdut Bharata bisa dikatakan eksis karena telah memiliki tiga hal yang menjadi syarat bagi sebuah grup agar bisa dikatakan eksis, yaitu memiliki strategi, konsistensi, dan adanya pengakuan dari masyarakat.

\section{Strategi}

Salah satu faktor yang sangat berpengaruh dalam menjaga eksistensi sebuah grup musik yaitu dengan adanya strategi yang dimiliki grup musik tersebut dalam menjaga eksistensinya. Strategi digunakan untuk merencanakan hal apa saja yang akan dilakukan grup guna menjaga eksistensinya. Dalam hal strategi, grup musik dangdut Bharata sampai saat ini sudah menjalankan strategi yang disiapkan oleh pimpinan grup. Strategi yang dilakukan pun mencangkup berbagai aspek yaitu aspek publikasi, penyajian, serta aspek lain seperti penataan panggung, pemilihan kostum, dan pembentukan karakter musik. Tentunya hal-hal tersebut dilakukan guna mempertahankan eksistensi grup musik dangdut Bharata hingga saat ini.

\section{Strategi Pemasaran}

Pemasaran merupakan faktor penting yang harus diperhatikan sebuah grup untuk bisa menjaga keberadaannya. Faktor inilah yang membuat sebuah grup bisa terus menjaga eksistensinya yaitu dengan dikenal luas oleh masyarakat sebagai konsumen sehingga grup tersebut terus mendapat tawaran untuk mengisi acara hiburan secara terus menerus. Selain itu, hal ini juga dapat membuat masyarakat mengetahui bagaimana kualitas sebuah grup tersebut baik dalam hal kualitas musik atau kualitas penampilan visual. Menurut Kotler dan Keller (2009:5) pemasaran adalah suatu proses sosial dan manajerial yang didalamnya individu dan kelompok mendapatkan apa yang mereka butuhkan dan inginkan dengan menciptakan, menawarkan dan menukarkan produk dan jasa yang bernilai dengan pihak lain.

Teori diatas dirasa sesuai dengan pemasaran yang dilakukan oleh grup musik dangdut Bharata karena grup tersebut menciptakan, menawarkanjasa hiburan, sehingga konsumen tersebut mendapatkan apa yang mereka butuhkan yaitu berupa jasa hiburan. Menurut wawancara yang penulis lakukan dengan pimpinan grup yaitu Bapak Juni Sunendar, beliau 
berkata bahwa saat ini grup musik dangdut Bharata lebih sering melakukan pemasaran melalui media sosial, yaitu Blackberry Mesanger (BBM). Beliau sebenarnya ingin juga memanfaatkan internet untuk publikasi, yaitu dengan membuat channel youtube dan mengunggah video grup musik dangdut Bharata ke internet, sehingga penampilan grup musik dangdut Bharata dapat ditonton oleh masyarakat luas, tidak hanya sekitar Kecamatan Salem saja. Namun hal itu terhambat oleh koneksi internet di sekitar Kecamatan Salem yang masih sulit, sehingga proses publikasi yang berhubungan dengan penggunggahan video dengan ukuran besar masih sulit dilakukan

\section{Strategi Penyajian Musik}

Pada umumnya penyajian Grup musik dangdut koplo berkarakter pada penyanyinya yang atraktif, dengan kostum yang seksi juga goyangannya yang enerjik. Oleh karena itu grup musik dangdut Bharata ingin menampilkan sesuatu yang berbeda dengan grup dangdut koplo lain. Grup musik dangdut Bharata ingin menampilkan performance penyanyipenyanyi pilihan. Dalam memilih penyanyi diperlukan penyeleksian terlebih dahulu, tidak hanya goyangannya yang enerjik namun suara serta kepiawaian dalam mengambil hati para penonton sangat diperhatikan. Selain penyanyi, faktor yang diperhatikan oleh grup musik dangdut Bharata adalah kelengkapan alat dan tata panggung yang megah. Sehingga dapat menarik minat penonton untuk menyaksikan penampilan grup musik dangdut Bharata.

Pada saat ini, penonton tidak hanya memperhatikan suara yang dihasilkan oleh sebuah grup dalam setiap pementasan, namun sudah memperhatikan permainan musik para musisi, tata panggung, kostum grup, bahkan tata lighting. Hal-hal tersebut memang dirasa sangat berpengaruh, karena saat ini para konsumen lebih selektif memilih grup mana yang bisa menghasilkan penampilan panggung yang lebih baik, maka grup tersebut akan lebih laris di pasaran. Dari semua yang dilakukan oleh grup musik dangdut Bharata bertujuan untuk kepuasan masyarakat sebagai penikmat musik.

\section{Strategi Penampilan panggung}

Dalam sebuah grup musik, selain kualitas musik yang dihasilkan, penampilan panggung merupakan salah satu hal yang memberikan pengaruh besar agar grup tersebut dapat terus mengembangkan dan menjaga eksistensinya. Penampilan panggung merupakan salah satu hal penting karena penampilan panggung merupakan bentuk visual dari grup tersebut yang langsung dilihat oleh penonton pada saat pementasan.

Salah satu bentuk ciri khas yang dimiliki grup musik dangdut Bharata lainya yaitu dalam hal Penampilan panggung. Penampilan panggung yang dibahas dalam penulisan ini yaitu meliputi : Kostum yang digunakan penyanyi serta pemain musik dan tata panggung serta Perlengkapan panggung dalam setiap pementasan grup musik dangdut Bharata.

\section{Konsistensi}

Konsistensi adalah melakukan suatu kegiatan secara terus menerus dengan tekun dan benar tanpa keluar dari jalur atau batasan batasan yang telah di tentukan maupun sesuai dengan ucapan yang telah dilontarkan(febriirawanto.blogspot.com/2012/07).Kon sistensi yang dilakukan grup musik dangdut Bharata yaitu dalam hal berusaha untuk mempertahankan ciri khas yang ada dalam musik dan berusaha meningkatkan kualitas musik dan penampilan panggung dalam setiap pemantasan. Hal itu dibuktikan dengan meningkatnya kualitas musik yang dihasilkan, dengan menggunakan teknologi yang berkembang saat ini dan dengan terus bertambahnya alat musik yang digunakan dalam pementasan. Dengan kualitas musik yang dimiliki, grup ini juga pernah menjadi juara pertama dalam sebuah perlombaan tingkat kabupaten yang diselenggarakan oleh PAMMI di Bumiayu.

Grup musik dangdut Bharata pun selalu konsisten dalam menjaga profesionalisme yaitu dengan menjaga kedisiplinan semua anggota grup. Dimulai dengan penyanyi, pemain musik dan semua 
crew yang terlibat. Dalam setiap penampilan, pimpinan grup selalu menghimbau agar tidak ada yang datang terlambat, karena bisa menghambat jalannya show. Hal itu sudah diterapkan dari awal grup musik dangdut Bharata ini berdiri, sehingga semua crew sudah mengerti peraturan yang dimiliki grup. Pimpinan grup musik Bharata mengatakan bahwa jika grup mengalami kekurangan dalam penyajian hiburan, makagrup siap menerima potongan harga sesuai dengan kekurangan yang dialami pada saat penampilan tersebut. Hal seperti itu merupakan sebuah konsistensi yang dimiliki oleh grup musik dangdut Bharata.

Selain konsisten dalam menjaga profesionalisme, grup musik dangdut Bharata juga konsisten dalam menjaga performa dalam setiap penampilan. Pemilihan penyanyi yang memiliki paras cantik dan kemampuan menyanyi yang baik, membuat setiap penampilan grup ini ramai oleh penonton. Pemain musik pun tidak kalah enerjik dengan penyanyi, karena disetiap lagu yang dibawakan, mereka biasanya melakukan gerakan yang senada mengikuti alunan lagu. Grup ini juga selalu konsisten dalam membawakan lagu-lagu terbaru yang keluar di pasaran. Dalam setiap penampilan, grup musik dangdut Bharata juga selalu bisa melayani permintaan lagu yang diminta oleh penonton atau saibul hajat.

Diluar jadwal mereka dalam mengisi hiburan di acara hajat, grup musik ini juga aktif di bidang sosial. Pada tahun 2010, tepatnya tanggal 10 Oktober grup musik dangdut Bharata mengadakan penggalangan dana yang di adakan dilapangan Desa Bentarsari. Penggalangan dana tersebut ditujukan untuk membantu korban gunung merapi yang saat itu membutuhkan bantuan. Dari acara penggalangan dana tersebut grup musik dangdut Bharata dibantu oleh pemuda pancasila Desa Bentarsari berhasil mengumpulkan dana sebesar 18 juta rupiah yang secara keseluruhan dana tersebut di salurkan bagi saudara kita yang menjadi korban bencana merapi pada saat itu.

Pengakuan dari Masyarakat
Hal terakhir sebagai syarat eksistensi suatu grup musik yang telah didapatkan oleh grup musik dangdut Bharata yaitu pengakuan. Grup musik dangdut Bharata sebagai grup musik tertua yang ada di Kecamatan Salem tentunya sudah dan terus mendapatkan pengakuan dari masyarakat. Hal yang mendasar dari pengakuan tersebut yaitu masih banyaknya jadwal pementasan yang dilaksanakan oleh grup musik dangdut Bharata. Untuk bulan November tahun 2015 saja, grup musik dangdut Bharata sudah melaksanakan enam kali pementasan.

Pementasan grup musik dangdut Bharata pada bulan November tersebar di beberapa tempat baik di dalam Kecamatan Salem maupun diluar Kecamatan Salem. Pementasan yang dilakuan grup musik dangdut Bharata pada bulan november seluruhnya merupakan acara hajat. Untuk sekali pementasan, penanggap atau konsumen yang ingin mendatangkan grup musik dangdut Bharata untuk mengisi hiburan harus mengeluarkan dana yang tidak sedikit. Penanggap harus mengeluarkan dana sebesar 6 juta rupiah untuk siang hari dengan durasi 6 jam. Sedangkan untuk acara hiburan yang diselengarakan dari siang hingga malam, dana yang dikeluarkan lebih besar lagi yaitu mencapai 10 juta rupiah dengan durasi penampilan siang dan malam sebanyak 10 jam.

Walaupun grup musik dangdut Bharata termasuk ke dalam grup musik dengan tarif yang cukup mahal di daerah tersebut, namun hingga saat ini grup musik dangdut Bharata masih banyak menerima tawaran pentas di berbagai acara. Bahkan grup musik dangdut Bharata saat ini sudah mendapatkan 3 kontrak untuk melakukan pementasan pada bulan februari dan 6 kontrak pada bulan maret tahun 2016. Hal ini menunjukan bahwa pengakuan masyarakat tentang keberadaan grup musik dangdut Bharata cukup besar. Pengakuan lain yang didapatkan grup musik dangdut Bharata yaitu dengan adanya sekelompok anak muda yang berasal dari Desa Salem menamai kelompok mereka dengan anama Bharata Fans Club.

Alasan mereka membentuk kelompok ini yaitu berdasarkan kesukaan mereka terhadap 
penampilan grup musik dangdut Bharata di setiap penampilan yang mereka lihat. Kelompok yang terdiri dari 10 - 15 orang ini selalu ada jika grup musik dangdut Bharata mengadakan pementasan di Kecamatan Salem. Kelompok ini selalu berada di barisan penonton paling depan. Dalam bebrapa lagu yang dibawakan grup musik dangdut Bharata, kelompok ini melakukan gerakan joget poco - poco yang terlihat kompak. Dengan adanya kelompok ini, pengkuan masyarakat tentang keberadaan grup musik dangdut Bharata sudah tidak diragukan lagi.

\section{SIMPULAN}

Musik dangdut merupakan musik yang sudah tidak asing lagi bagi kehidupan masyarakat di sekitar Kecamatan Salem, Kabupaten Brebes. Karena dalam setiap hari besar atau acara khajatan, sebagian besar acara hiburan di isi dengan pergelaran musik dangdut. Hal itu membuktikan bahawa musik dangdut sudah menjadi bagian dari kehidupan sosial masyarakat di Kecamatan Salem.

Bharata merupakan sebuah grup musik dangdut yang berasal dari Desa Bentar, Kecamatan Salem, Kabupaten Brebes yang hingga kini masih diakui keberadaannya. Hal ini dikarenakan grup ini dapat mengelola manajemen dengan baik dalam hal pemasaran, dan konsistensi dalam meningkatkan serta menjaga kualitas musik maupun penampilan dalam setiap pementasan. Oleh karena itu hingga saat ini keberadaan grup ini terus di akui oleh masyarakat dan membuat grup ini tetap eksis hingga saat ini.

\section{REFRENCE}

Aesijah, S. (2011). MUSIK DANGDUT: SUATU KAJIAN BENTUK MUSIK. Harmonia: Journal Of Arts Research And Education, 10(1). doi:http://dx.doi.org/10.15294/harmonia.v10i1.5

Alviani, E. (2013). BENTUK PERTUNJUKAN ORKES DANGDUT PARODI SENGGOL TROMOL DI SEMARANG: KAJIAN BENTUK DAN FUNGSI. Harmonia: Journal Of Arts Research And Education, 12(1). doi:http://dx.doi.org/10.15294/harmonia.v12i1.2 2160
Ambarwangi, S., \& Suharto, S. (2013). PENDIDIKAN MULTIKULTURAL DI SEKOLAH MELALUI PENDIDIKAN SENI TRADISI. Harmonia: Journal Of Arts Research And Education, 13(1). doi:http://dx.doi.org/10.15294/harmonia.v13i1.2 535

Hadi, Irfan A. 2015. Eksistensi Komunitas Waroeng Keroncong di Kota Semarang. Skripsi: FBS UNNES Semarang.

Irawati, I. R. 2000.”Musik Jazz dan Dangdut dalam Analisis Stratifikasi Sosial dalam Masyarakat"Jurnal Sosiologi. Jakarta: PT Gramedia Pustaka Utama.

Kotler, Philip, dan Kevin Lane Keller. 2009. Manajemen pemasaran jilid1. Edisi ke sembilan, Terjemahan Drs. Alexander Sindoro. Jakarta : PT. Indeks.

Moleong, Lexy J. 2007. Metodologi Penelitian Kualitatif. Bandung: PT. Remaja Rosdakarya

Muttaqin, Moh. 2003. "Musik Dangdut: Sebuah kajian Musikologis": Tesis Pasca Sarjana.

Ukat.1990.”Dangdut Mapan “dalam Majalah Citra Musik. Jakarta.

William H. Frederick, 1982."Roma Irama and The Dangdut Style: Aspect of Contemporary Popular Culture". Indonesia no. 34 tahun 1982; lihat juga Adi "Dangdut " Nugroho, "Dangdut Goes Global, Why Not?" http://ito.ourfamily.com/maj/opini.htm posted 3 Agustus 2000.

Haryono, S. (2011). DANGDUT DAN EKSPLOITASI SEKS PEREMPUAN (Dangdut and Woman Sex Exploitation). Harmonia: Journal Of Arts Research And Education, 3(2). doi:http://dx.doi.org/10.15294/harmonia.v3i2.68 8 